\title{
Perception of School Stakeholders on Shadow Education in Iringa Municipality, Tanzania
}

\author{
Kassim Peter Mlawa \\ Orcid: https://orcid.org/0000-0002-5685-5900 \\ Department of Curriculum and Instruction, Open University of Tanzania, Tanzania \\ Email: kassimmlawameci@gmail.com \\ Evaristo Andreas Mtitu, PhD \\ Orcid: https://orcid.org/0000-0002-5251-5124 \\ Department of Curriculum and Instruction, Open University of Tanzania, Tanzania \\ Email: evaristo.mtitu@out.ac.tz
}

Corresponding Mail: kassimmlawameci@gmail.com

\begin{abstract}
Copyright resides with the author(s) in terms of the Creative Commons Attribution CC BY-NC 4.0. The users may copy, distribute, transmit and adapt the work, but must recognize the author(s) and the East African Journal of Education and Social Sciences
\end{abstract}

\begin{abstract}
This study investigated on the perception of school stakeholders on shadow education in Iringa Municipality through mixed approach and descriptive design. A sample of 50 participants was drawn out of 58 Education Stakeholders from six Education Centers. Participation was voluntary and participants had the right to withdraw any time. Questionnaire and interview schedule were sources of data. Qualitative data was treated thematically in that common themes were assembled together to address the research question. Quantitative data was presented descriptively through numbers. The study established that school stakeholders held a positive perception toward the shadow education as compared to the mainstream education as the shadow education system boosted the academic performance of the students. It is therefore recommended that the government through the ministry of Education and Vocational Training needs to make much greater attention to shadow education centers which seem to affect the performance of teachers in mainstream education system.
\end{abstract}

Keywords: Shadow Education; Academic Performance; Mainstream school; private tutoring

How to cite: Mlawa, K. P. and Mtitu, E. A.. (2022). Perception of School Stakeholders on Shadow Education in Iringa Municipality, Tanzania. East African Journal of Education and Social Sciences 3(1), 89-93. Doi: https://doi.org/10.46606/eajess2022v03i01.0150.

\section{Introduction}

Shadow Education is one that is offered outside normal classroom sessions as a measure to enable learners improve their academic performance in examinable subjects (Byun, 2014; Bray, 2017). According to Yung and Bray (2017), shadow Education is the teaching of academic subjects that is offered outside school hours for financial gain. The term "shadow education" is further referred to as private by informal education institutions or by individual teachers or outsiders out of school premises (Silova, Budiene \& Bray, 2006). Bray (2012) considers shadow education as one that is offered to students outside normal classroom sessions but is parallel with mainstream schooling. Baker, Akiba, LeTendre and Wiseman (2001) further explained Shadow Education as the measures to assist students improve their performance.

Shadow education is evident in many countries including Hong Kong, Sri Lanka, Republic of Korea Pakistan, India, Brunei, Malaysia, the Philippines, Singapore, Thailand and Vietnam (Anangisye, 2016, Bray, Zhan, Lykins, Wang, Kwo, \& Ora, 2014). In Africa, shadow education has been observed in countries like Egypt, Mauritius, Morocco, South Africa, Kenya, Uganda and Zimbabwe (Lee, 2013). 
For example, in Egypt, a 2004 study estimated that households devoted $61.0 \%$ of education expenditures to private tutoring. The 8-4-4 system in Kenya has been characterized with heavy workload on both students and teachers to the extent that the syllabus necessitates extra tuition in the evenings, over the weekends and during holidays (Mwania \& Moronge, 2018).

Shadow education in Tanzania is widespread (Mbele \& Katabaro, 2003). Its main purpose is to complement on what has been learnt by pupils at school (Kabage, 2015). In 1998, the United Republic of Tanzania through her Ministry of Education and Culture (MOEC) banned the provision of shadow education in school premises with effect from $1^{\text {st }}$ January, 1999 (Jamhuri ya Muungano wa Tanzania, 1998). However, this has not prevented the education stakeholders from seeking services from providers of shadow education possibly because of the weaknesses that has been observed in the mainstream education system. For instance, Anangisye (2016) identified a types of Shadow Education in terms of the use of remedial classes that is dominant in Tanzania and is conducted by teachers in different education centers which are aimed at raising academically weak pupils to cope with the fast learners. Kabage (2015) further adds that, in Tanzania, teachers would run some private tutorials to their own pupils after school hours as a way to complement what was not done in the normal classroom as well as generating some additional income by means of charges collected from the students.

Education centers are institutions which are concerned with provision of shadow education outside the mainstream schooling (Malik, 2017). The centers have been struggling to improve the performance of students which has gained popularity in recent times as the best way of supplementing deficiencies in mainstream education (Mbelle \& Katabaro, 2003). According to Subed (2018), shadow education has provided chances for education stakeholders like teachers and education centers owners to improve their wellbeing through service fees.

Despite potential advantages of shadow education system, there are several issues which arise like social gaps between those parents who can afford to pay private tuition fees versus those who cannot afford those expenses. Another issue is inadequate service provided by teachers in schools because they are dedicated in private tutoring centres, thus using limited time and energy for teaching in schools; therefore teaching quality in schools become very poor (Jamhuri ya Muungano wa Tanzania, 1998); Anangisye,2016).

Contrary to Tanzania education curriculum of 2005, 2007 and 2015, which emphasized on the application and use of Competence Based Curriculum ( $\mathrm{CBC})$, shadow education aims at teaching students to pass their final examinations, thus resulting to rote learning rather than gaining competency which would help them to apply in their real life situations (Zhang \& Bray, 2017).

This study sought to investigate on perception of stakeholders on shadow education in Iringa Municipality, and was guided by the following research question: How do education stakeholders perceive the contribution of shadow education on secondary school students' academic performance?

\section{Literature Review}

This section presents the literature related to the study under some subtitles:

\section{Shadow Education}

Subed (2018) defined Shadow Education as offering private tutoring by informal education institutions or by individual teachers outside the mainstream schooling. Silova, Budiene and Bray (2006) have it that shadow education is a common phenomenon that offers private supplementary tutoring.

Bray (2017) drew the attention to educational policymakers by documenting the growth of shadow education worldwide and in the process, developed a detailed definition by which learning activities can be considered as shadow education as follows:

Supplement: Shadow education is supplementary in nature because it addresses subjects already covered in school.

Market: Shadow education is provided in exchange with a fee. It is opposed to unpaid tutoring provided by families or community members, or extra tutoring provided by school teachers as part of their professional commitment and responsibility.

Academic: Shadow education covers examinable subjects including languages and mathematics, but excludes musical, artistic or sporting skills which are learned primarily for pleasure and/or for a more rounded form of personal development.

Subed (2018) defined shadow education as private teaching and learning provided in informal 
education institutions by individual teachers outside school premises. On the other hand, Buchman, Condron and Roscigno (2010) defined shadow education as educational activities such as tutoring and extra classes occurring outside the formal learning; it is designed to increase student's chance of passing.

According to Bray and Silova (2006), shadow education through private tutoring is a growing phenomenon in the world. Subed (2018) further adds that, the teaching and learning environment in the mainstream education system does not guarantee the provision of quality education, leading to education stakeholders looking for Alternatives via Shadow Education.

\section{Pros and Cons of Shadow Education}

Crotty (2012) declared that private tutoring is a highly effective way to ensure academic excellence through compensating the weaknesses from the mainstream schooling. Bray and Lykins (2012) argued that benefits of private tutoring are unarguable since the system supports the mainstream schooling by helping students to perform well in examinable subjects. The very purpose of shadow education is to supplement the mainstream education (Bray, 2007).

Proponents of shadow education argue that it increases syllabus coverage rates and improves performance (Muindi, 2012). Subed (2018) has it that positive consequences of private tutoring include improved learning outcomes through immediate support and feedback from teachers which enhance students' development of selfconfidence.

There are negative consequences of private tutoring such as lack of students' attention during formal classroom hours and extra financial burden to parents. Furthermore, private tutors may distort the curriculum in the mainstream system, upsetting the sequence of learning in the mainstream system in order to gain benefits through private teaching (Mwania \& Moronge, 2018).

\section{Methodology}

This section presents the methodology that guided the study:

\section{Research Design}

This study employed the mixed approach which Cresswell (2009) defined as one which uses both qualitative and quantitative paradigms concurrently.
The qualitative approach used words while the quantitative approach used numerals. The study used the descriptive research design and questionnaire and interview schedule as sources of data.

\section{Population of and Sampling}

The population of the study was 58 Education Stakeholders (teachers, students, parents, business people from six Education Centers in Iringa Municipality and the District Education Officer). A sample of 50 participants was involved in the study through purposive and simple random sampling techniques.

\section{Validity and Reliability}

To minimize the faulty of feedback and maximize correct information, the instruments were subjected to two research experts from Ruaha Catholic University to go through and give feedback on what had to be improved prior to the data collection process. Corrections were made accordingly. The interview was conducted in Kiswahili and then translated into English with the help of some teachers from Lugalo Secondary School who are fluent in both Kiswahili and English as some of respondents would not articulate very well in English.

\section{Statistical Treatment of Data}

Qualitative data was treated thematically in that common themes were assembled together to address the research question. The quantitative data was presented descriptively through numbers.

\section{Ethical Considerations}

The researchers maintained confidentiality and anonymity of the participants. In this case, pseudo names and not participants' real names were used. Also the researchers demanded signatures to consent forms prior to data collection. Participation was completely voluntary and participants had the right to withdraw any time.

\section{Findings and Discussion}

This study was guided by one research question: how do Education Stakeholders' Perceive the Contribution of Shadow Education on Secondary School Students' Academic Performance?

Education stakeholders were provided with a closed ended questionnaire with the Likert Scale options arranged from Agree and Disagree. Respondents were supposed to put a tick $(V)$ against the appropriate option whether shadow education 
has a positive contribution to secondary schools' Academic Performance or not as appears in table 1.

Findings in table 1 indicate that large percent of respondents (98\%) agreed that shadow education has positive contribution to students' academic performance. This concurs with findings by Zhang and Bray (2020) in their study on Shadow Education: Achievements, challenges and the agenda ahead. The study revealed that Shadow Education has spread all over the world and most countries practice it in different forms after realizing its positive contribution on students' academic achievement. However, small percentage (2\%) of respondents in table 1 considered it as useless because it interferes with the governments' efforts. The finding agrees with those by Anangisye (2016) who found out that Shadow Education leads to exploitation of students, development of social inequality, encouragement of rote learning and exploitation of government resources.

Table 1: Stakeholders' Perceptions on the Contribution of Shadow Education

\begin{tabular}{lcccccc}
\hline \multicolumn{1}{c}{ Respondents } & \multicolumn{2}{c}{ Agree } & \multicolumn{2}{c}{ Disagree } & \multicolumn{2}{c}{ Total } \\
& $\mathbf{N}$ & $\mathbf{\%}$ & $\mathbf{N}$ & $\mathbf{\%}$ & $\mathbf{N}$ & $\mathbf{\%}$ \\
\hline Teachers & 20 & 40 & 0 & 0 & 20 & 40 \\
Students & 15 & 30 & 0 & 0 & 15 & 30 \\
Parents & 10 & 20 & 0 & 0 & 10 & 20 \\
Education Centre Owners & 4 & 8 & 0 & 0 & 4 & 8 \\
District Officers & 0 & 0 & 1 & 2 & 1 & 2 \\
TOTAL & $\mathbf{4 9}$ & $\mathbf{9 8}$ & $\mathbf{1}$ & $\mathbf{2}$ & $\mathbf{5 0}$ & $\mathbf{1 0 0}$ \\
\hline
\end{tabular}

Through interview, one student declared that: "shadow education is very useful to me because teachers teach well and are more close, cooperative and assist students especially when we face academic challenges" (Student Center A (8/2/2021). The respondent shows that teachers from shadow education centers have been so helpful for they helped him when he faced academic challenges.

Another respondent had the following to say: "I attend shadow education for extra tuitions because teachers from these centers are well understood, motivated and teach in a friendly way than teachers from school" (Student Center C (10/2/2021). This suggests that the respondent did not trust the teachers from the mainstream schooling, rather she considers teachers in shadow education centers as better than those from mainstream schooling.

One of the parents said: "One of the good things I do find in shadow education center is the rise of students' confidence, hence enabling them to pass examinations; Once my son failed his Form Two examinations, I decided to send him to shadow education for extra tutoring. What I have observed is that my son passed his subsequent examinations with higher grades (Parent: Center D (11/2/2021). This show that the parent has been encouraged and got satisfied with the quality of education provided by the shadow education center.

\section{Conclusions and Recommendations}

\section{Conclusions}

It is concluded that school stakeholders hold a positive perception toward the shadow education as compared to the mainstream education as the shadow education system boosted the academic performance of the students.

\section{Recommendations}

It is recommended that the government through the ministry of Education and Vocational Training needs to make greater attention to shadow education centers for they have impact on the policy implementation. The government needs to take deliberate intentions to raise teachers' salaries in order to retain teachers in schools and avoid their movement looking for more payment through shadow education.

\section{References}

Anangisye, W.A.L, (2016). A Review of the Longstanding Ban on Private Supplementary Tutoring in Tanzania Mainland. Dar es Salaam University College of Education \& School of Education, University of Dar es Salaam.

Baker, D. P., Akiba, M., LeTendre, G. K., \& Wiseman, A. W. (2001). Worldwide shadow education: Outside-school learning, institutional quality of schooling, and cross-national mathematics achievement. Educational Evaluation and Policy Analysis, 23, 1-17.

Bray, M. (2017). Schooling and its supplements: Changing global patterns and implications for comparative education. Comparative Education Review, 61, 469-491.

Bray, M. (2021). Shadow education in Africa. Private supplementary tutoring and its policy 
implications Hong Kong: Comparative Education Research Centre (CERC).

Bray, M. (2017). Schooling and its supplements: Changing global patterns and implications for comparative education. Comparative Education Review, 61, 469-491.

Bray, M., \& Lykins, C. (2012). Shadow Education. CERC Monograph Series in Comparative and International Education and Development No. 9. Philippines: Asian Development Bank.

Bray, M. and Silova, I. (2006). The private tutoring phenomenon: International patterns and perspectives. Budapest: Open Society Institute, pp. $27-40$.

Bray, M., Zhan, S., Lykins, C., Wang, D., \& Kwo, Ora. (2014). differentiated demand for private supplementary tutoring: Patterns and implications in Hong Kong secondary education.Economics of Education Review, 38, 24-37.

Buchmann, C., Condron, D. J., \& Roscigno, V. J. (2010). Shadow education: Theory, analysis and future directions: A rejoinder. Social Forces, 89(2), 483-490.

Byun, S.Y. (2014). Shadow education and academic success in South Korea. In Park, H. \& Kim, K. (Eds.), Korean Education in Changing Economic and Demographic Contexts. Dordrecht: Springer, pp.39-58.

Cresswell, J.W.(2009). Research design: Qualitative and Quantitative methods approaches. California, USA: Age Publications Ltd.

Crotty, J.M. (2012). Global private tutoring market will surpass $\$ 102.8$ billion by 2018 . Forbes Magazine,300ctober.Availableonline:http:// www.forbes.com/sites/jamesmarshallcrotty /2012/10/30/global-private-tutoring-marke t-will-surpass-102-billion-by2018, accessed 30 November 2013.

Jamhuri ya Muungano wa Tanzania (1998). Mafunzo ya Ziada (Tuition) katika shule za Sekondari na Msingi. Dar es Salaam: Ministry of Education and Culture.

Kabage, J.(2015). Private Tutoring and Distance Learning Process at the Open University of Tanzania. Unpublshed Master of Education in Open And Distance Learning of the the Open University of Tanzania, Tanzania.

Lee, (2013). Private tutoring and its impact on students' academic achievement, formal schooling, and educational inequality in Korea. Unpublished Doctor of Philosophy, Columbia University, Columbia.

Malik, M. A. (2017). Shadow education: Evolution, flaws and further development of the term. Social Sciences and Education Research Review, 4(1), 6- 29.

Mbelle, A. and Katabaro, J (2003). School enrolment, performance and access to education in Tanzania. Dar es Salaam: Nyota and Mkuki Publishers Ltd.

Muindi, P. (2012). Education Minister Bans Holiday Coaching. Daily nation, 15th August 2012.

Mwania, J.k, \& Moronge, M. (2018). An Analysis of Sadow Education on Mainstream Education in Public Secondary Schools in Athi River District. African Journal of Education and Practice, 1(2): 56-76.

Silova, I., Budiene, V. \& Bray, M. (2006).Education in a Hidden Marketplace: Monitoring of private tutoring. EducationSupport Program (ESP) of the Open Society Institute.Budapest.

Subed, K.R.(2018). Shadow Education: A role of Private Tutoring in Learning. International Journal of Humanities and Social Sciences. Open Access International Journal, 1(2) :2942.

Yung, K. W. H., \& Bray, M. (2017). Shadow education: Features, expansion and implications.In T. K. C. Tse \& M. Lee (Eds.), Making sense of education i post-handover Hong Kong: Achievements and challenges (pp. 95-111). London: Routledge.

Zhang, W., \& Bray, M. (2020). Comparative research on shadow education: Achievements, challenges and the agenda ahead. European Journal of Education, 55 (3), 322-341.

Zhang, W., \& Bray, M. (2017). Micro-neoliberalism in China: Public-private interactions at the confluence of mainstream and shadow education. Journal of Education Policy, 32(1), 63-81. 